
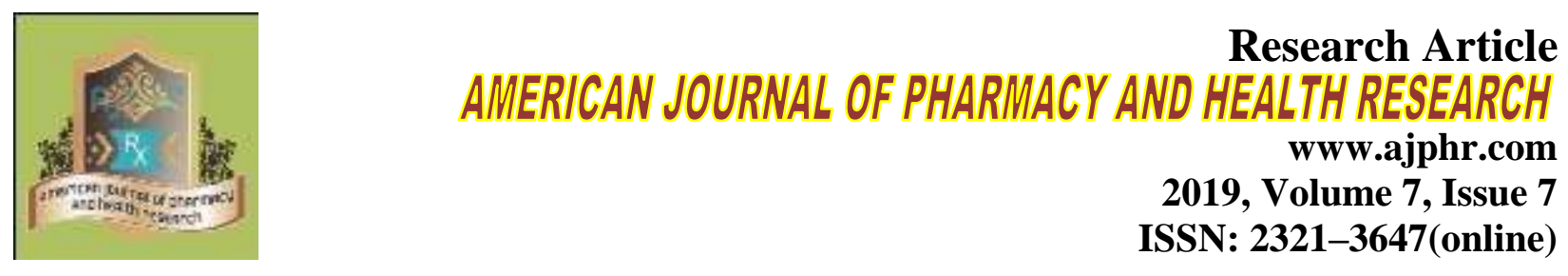

\title{
Formulation and Comparative Evaluation of Diclofenac Aqua Gel by Using Various Polymers
}

\author{
Smita More*, Mohini Upadhyay, Sohini Ganguly \\ PES's Modern College of Pharmacy (For Ladies), Moshi, Tal- Haveli
}

\begin{abstract}
Aqua gel is a polymeric gel formulated by using crosslinking agent to form a network of crosslinked polymer chains. It is a hydrophilic structure with capability of holding water in their three-dimensional networks. Formulation and comparative evaluation of Diclofenac aqua gel by using various polymers have been carried out to check efficient concentration of various polymers as well as to choose an appropriate polymer. Diclofenac has chosen as an active pharmaceutical ingredient which have tendency to cause acidity or GI irritation when comes in contact with GI fluid. Avoidance of such side effect is one of the motives of this research. Administration of Diclofenac trans dermally will avoid to get contact with GI fluid as well as avoid GI irritation. In this research various concentration of polymer has been taken to compare between polymer concentration as well as various polymer efficiency.
\end{abstract}

Keywords: Aqua gel, Hydrogel, topical gel, Diclofenac gel, hydrophilic gel. 


\section{INTRODUCTION}

Aqua gel is hydrophilic gel formulated by using various polymers and cross-linking agents which produce three-dimensional networks. It has capability to consume great amount of water hence it is referred as hydrogel. Aqua gel can be formulated by using either synthetic polymer or natural polymer. ${ }^{[1]}$

Oral route is the popular route of drug delivery. Although it has some disadvantages including first pass metabolism, drug degradation in gastrointestinal tract due to enzymes, $\mathrm{pH}$, acidity due to drug administration to cross such problems, a novel drug delivery system was developed. In topical drug delivery system studies aqua gels are prepared which deliver therapeutically effective amount of drug across the skin when it is applied on skin. Once applied on unbroken skin, they deliver active ingredients into systemic circulation passing via skin barriers. aqua gel containing required dose of drug retained on the skin for specific period of time, which then enters into blood stream by diffusion process. Drug can penetrate through skin by three pathways like hair follicles, sebaceous glands and sweat duct. ${ }^{[2]}$

Now a day's scientific advances have been made in the research and development of aqua gel drug delivery systems by overcoming physiological adversities such as first pass metabolism and for improved local action. Basically, aqua gels are three-dimensional, hydrophilic, polymeric networks capable of consuming large amounts of water or biological fluids. In this research, effect of different polymer as well as polymer concentration had been carried out. Two polymers have been used Carbopol and Hydroxy propyl methyl cellulose (HPMC). Three concentrations are taken of each polymer. After formulation of aqua gels, they are evaluated by using various evaluation parameters.

Diclofenac has been used as active pharmaceutical ingredient which is from the category NSAID. NSAID's are non-steroidal drugs having excellent anti-inflammatory and analgesic activity but NSAID's produces GIT ulceration, liver and kidney trouble especially in case of oral administration. To avoid such kind of disadvantage Diclofenac is prepared for trans dermal use which also avoid first pass metabolism. ${ }^{[2]}$

\section{MATERIALS AND METHOD}

\section{Materials}

Diclofenac, Carbopol 940, Guar gum, Isopropyl Myristate, Benzalkonium chloride, Distilled Water. Aqua gel consists of about $99 \%$ of water. Polymer and co polymers are selected as hydrophilic in nature and $0.1 \% \mathrm{NaOH}$ solution is used as a cross linking agent. 


\section{Preparation of Aqua gel}

- Various decided concentrations of Carbopol and guar gum and HPMC, guar gum are dispersed into distilled water and subjected to stirring on mechanical stirrer and kept for $24 \mathrm{hrs}$.

- Weighed amount of Diclofenac was added to above mixture at various concentration.

- Add $1 \% \mathrm{v} / \mathrm{v}$ Isopropyl myristate and $0.0025 \% \mathrm{w} / \mathrm{v}$ benzalkonium chloride.

- Add $0.1 \% \mathrm{NaOH}$ as cross-linking agent as well as $\mathrm{pH}$ adjuster. ${ }^{[4]}$

\section{Evaluation of gel}

Prepared gels were evaluated by using following parameters. Evaluation of gel performed to control their quality. Obtained results are mentioned in the session of result and discussion.

\section{RESULTS AND DISCUSSION}

\section{FORMULATION OF DICLOFENAC AQUA GEL}

Composition of Diclofenac aqua gel by using Carbopol as well as HPMC as polymer has shown in table 1.

Table 1: Formulation of gel by using Carbopol and HPMC as polymer

\begin{tabular}{llllllll}
\hline Sr.No. & Ingredient & A1 & A2 & A3 & B1 & B2 & B3 \\
\hline 1$)$ & Diclofenac Sodium (mg) & 100 & 100 & 100 & 100 & 100 & 100 \\
$2)$ & Crbopol-940(mg) & 0.5 & 1 & 1.5 & - & - & - \\
$3)$ & HPMC (gm) & - & - & - & 0.5 & 1 & 1.5 \\
$4)$ & Guar gum (gm) & 2.5 & 2 & 1.5 & 2.5 & 2 & 1.5 \\
$5)$ & Isopropyl Myristate(ml) & 1 & 1 & 1 & 1 & 1 & 1 \\
$6)$ & Benzalkonium Chloride & Q. S & Q. S & Q.S & Q. S & Q. S & Q. S \\
$7)$ & Distilled water & Q. S & Q. S & Q.S & Q. S & Q.S & sQ.S \\
\hline
\end{tabular}

\section{EVALUATION OF TOPICAL AQUA GEL ${ }^{[4]}$}

\section{Physical appearance}

The physical appearance in which color, texture, homogeneity of the prepared gels were tested by visual observations and results are demonstrated in table 2.

Table 2: Physical appearance of prepared aqua gel.

\begin{tabular}{lll}
\hline Parameters & $\begin{array}{l}\text { Aqua gel using } \\
\text { Carbopol } \\
(\mathbf{A 1}, \mathbf{A 2}, \mathbf{A 3})\end{array}$ & $\begin{array}{l}\text { Aqua gel using } \\
\text { HPMC } \\
\mathbf{( B 1 , ~ B 2 , ~ B 3 ) ~}\end{array}$ \\
\hline Colour & White & Yellowish \\
Texture & Smooth and opaque & Smooth and opaque \\
Homogeneity & Homogenous & Homogenous \\
Visual & Thick, translucent & Thick, translucent \\
appearance & & \\
\hline
\end{tabular}




\section{Spreadability test}

Two slides have been taken and take small amount of prepared gel which have spread by another slide tilted and checked spreadability as well as gritty nature of prepared gels. Spreadability and gritty nature of aqua gels have shown in table 3.

Table 3: Spread ability of prepared aqua gel.

\begin{tabular}{|c|c|c|}
\hline Parameters & $\begin{array}{l}\text { Aqua gel using } \\
\text { Carbopol } \\
(\mathbf{A} 1, \mathbf{A} 2, \mathbf{A} 3)\end{array}$ & $\begin{array}{l}\text { Aqua gel using HPMC } \\
\text { (B1, B2, B3) }\end{array}$ \\
\hline $\begin{array}{l}\text { Spreadability } \\
\text { Gritty nature }\end{array}$ & $\begin{array}{l}\text { Spreadable } \\
\text { None }\end{array}$ & $\begin{array}{l}\text { Spreadable } \\
\text { None }\end{array}$ \\
\hline
\end{tabular}

\section{pH Determination}

$1 \%$ solution of each prepared gel has prepared and measure $\mathrm{pH}$ by using calibrated digital $\mathrm{pH}$ meter and results are obtained as mentioned in table 4.

Table 4: Determination of $\mathrm{pH}$ of prepared aqua gel.

\begin{tabular}{lllllll}
\hline Parameter & A1 & A2 & A3 & B1 & B2 & B3 \\
\hline $\mathrm{pH}$ & 6.9 & 7.3 & 7.1 & 7.4 & 6.8 & 6.6 \\
Irritancy & Non- & Non- & Non- & Non- & Non- & Non- \\
test & Irritant & Irritant & Irritant & Irritant & Irritant & Irritant \\
\hline
\end{tabular}

\section{Determination of viscosity}

The viscosity of the gel formulations was determined using calibrated Brookfield viscometer with spindle no. 7 at $100 \mathrm{rpm}$ at the temperature of $25^{\circ} \mathrm{C}$ and results are obtained as shown on table 5 .

Table 5: Determination of viscosity of prepared aqua gel.

\begin{tabular}{ccccccc}
\hline Parameter & A1 & A2 & A3 & B1 & B2 & B3 \\
\hline $\begin{array}{c}\text { Viscosity } \\
\text { (cps) }\end{array}$ & 289.4 & 281.6 & 280.1 & 220.0 & 201.3 & 233.7 \\
\hline
\end{tabular}

\section{Drug Content}

Drug content of prepared Aqua gel has been measured by using 1 gm of each formulation in 20 $\mathrm{ml}$ of phosphate buffer $\mathrm{pH} 7.4$ and kept for $30 \mathrm{~min}$. The resultant mixture was filtered through membrane filter (pore size $0.45 \mu \mathrm{m}$ ). The absorbance of the sample was determined using UV spectrophotometry at $276 \mathrm{~nm}$ (UV-VIS spectrophotometer SHIMADZU UV-1800) after suitable dilution with phosphate buffer $\mathrm{pH}$ 7.4. The concentration of diclofenac sodium was estimated and shown in table 6.

Table 6: Determination of drug content of prepared aqua gel.

\begin{tabular}{ll}
\hline Formulation Batches & Drug Content \\
\hline A1 & $93.03 \%$ \\
A2 & $99.39 \%$ \\
\hline
\end{tabular}




\begin{tabular}{ll}
\hline A3 & $91.60 \%$ \\
B1 & $96.19 \%$ \\
B2 & $89.20 \%$ \\
B3 & $99.19 \%$ \\
\hline
\end{tabular}

\section{In vitro diffusion studies}

In vitro diffusion studies of optimized two formulated Aqua gels one contains Carbopol (A2) and second contains HPMC (B3) as polymer were carried out by using Egg membrane in Franz diffusion cell and obtained results are demonstrated in table 7 and graphically represented in figure 1 .

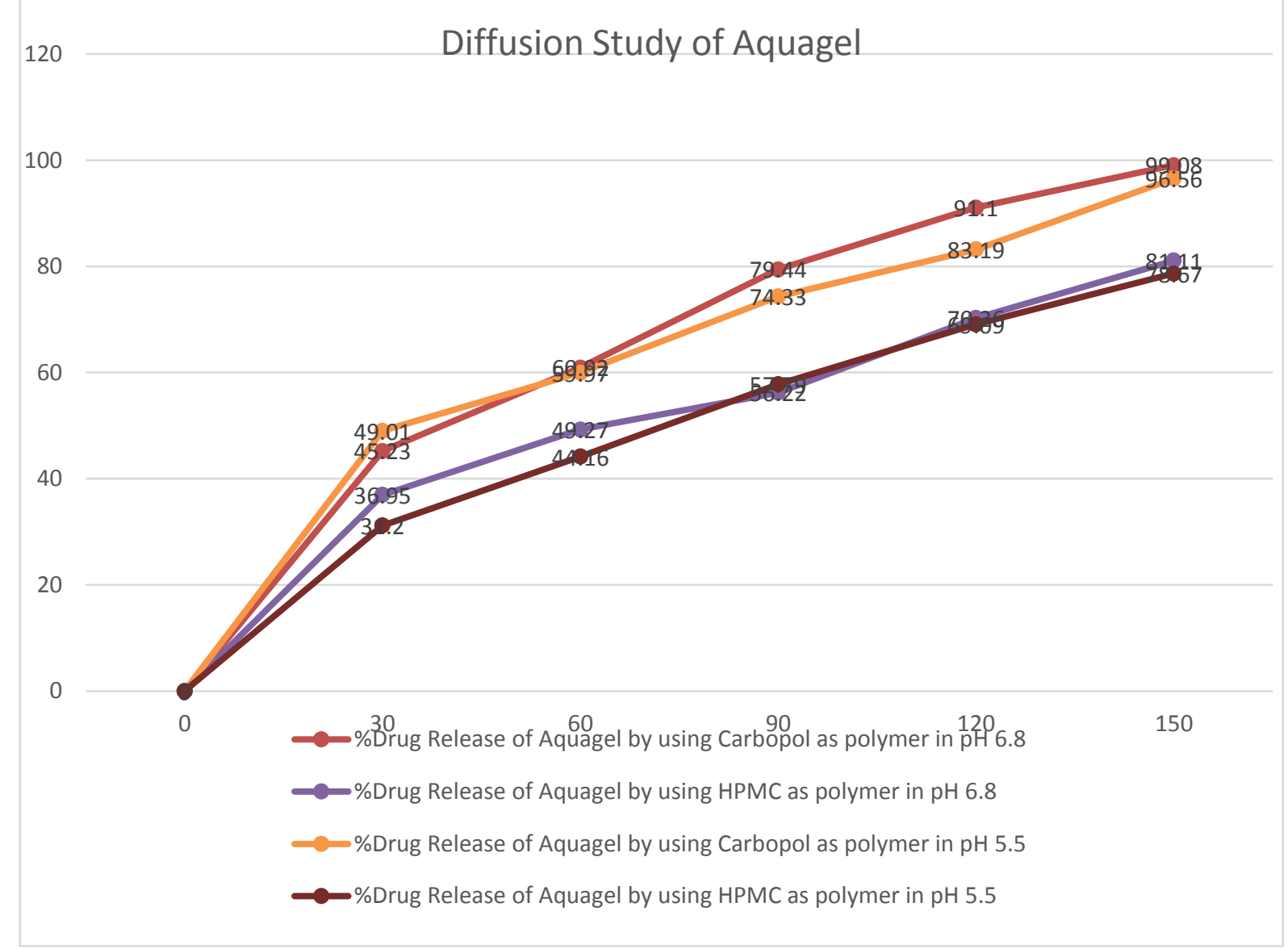

Figure 1: graph of diffusion studies of aqua gels

Table 7: In vitro diffusion study

\begin{tabular}{|c|c|c|c|c|c|}
\hline \multirow{2}{*}{$\begin{array}{l}\text { Sr. } \\
\text { No. }\end{array}$} & \multirow{2}{*}{$\begin{array}{l}\text { Time } \\
\text { Interval } \\
\text { (min) }\end{array}$} & \multicolumn{2}{|c|}{ \% Drug Release in pH 6.8} & \multicolumn{2}{|c|}{ \% Drug Release in pH 5.5} \\
\hline & & $\begin{array}{l}\text { Aqua gel by } \\
\text { Using Carbopol } \\
\text { As polymer } \\
\text { (A2) }\end{array}$ & $\begin{array}{l}\text { Aqua gel by } \\
\text { using HPMC } \\
\text { as polymer } \\
\text { (B3) }\end{array}$ & $\begin{array}{l}\text { Aqua gel by } \\
\text { Using } \\
\text { Carbopol as } \\
\text { Polymer(A2) }\end{array}$ & $\begin{array}{l}\text { Aqua gel by } \\
\text { using HPMC } \\
\text { as polymer } \\
\text { (B3) }\end{array}$ \\
\hline 1. & 30 & 45.23 & 36.95 & 49.01 & 31.20 \\
\hline 2. & 60 & 60.92 & 49.27 & 56.70 & 44.16 \\
\hline 3. & 90 & 79.44 & 56.22 & 64.33 & 57.79 \\
\hline$\underline{w w}$ & hr.c & & & & 5 \\
\hline
\end{tabular}




\begin{tabular}{llllll}
\hline 4. & 120 & 91.10 & 70.26 & 83.19 & 69.09 \\
5. & 150 & 99.08 & 81.11 & 96.56 & 78.67 \\
\hline
\end{tabular}

\section{CONCLUSION}

Topical Aqua gel of Diclofenac sodium was formulated by using two various polymers Carbopol-940 as well as HPMC and evaluated by using various evaluation parameters. Formulated gels are homogeneous in nature without any grittiness. They are thick, translucent and spreadable. By changing the route of administration of Diclofenac sodium can successfully avoid the first pass metabolism and can skip the adverse effect such as acidity occurs after administer of Diclofenac sodium. Change in polymer effect on release of drug after application on skin. Optimized Aqua gel has prepared by using Carbopol as polymer which was A2, shows more drug release than optimized Aqua gels prepare by using HPMC as a polymer which was B3.

\section{ACKNOWLEDGEMENT}

I wish to express my sincere gratitude to Modern College of Pharmacy (for ladies), Moshi, Pune, for providing necessary facilities required for this research work.

\section{REFERENCE}

1. http://en.m.wikipedia.org/wiki/self-healing_hydrogels

2. Chauhan S. Harikumar S. L. Hydrogels: a smart drug delivery system, Int J Res Pharm Chem. (2012). 2, 3: 2231-2781

3. Enas M. A. Hydrogel: Preparation, characterization, and applications. J Advanced Res 2015. 6: 105-121.

4. Monica A. S., Gautami J. Design and evaluation of topical hydrogel formulation of diclofenac sodium for improved therapy. Int J Pharma Sci Res 2014. 5, 5: 1973-1980.

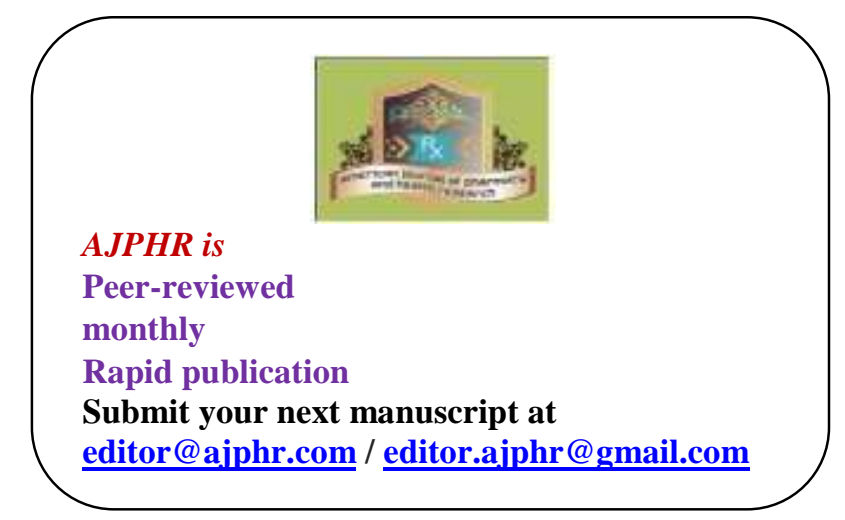

